Japan. J. Med. Sci. Biol., 21, 55-70, 1968

\title{
FURTHER INVESTIGATIONS ON THE INFLUENCE OF INORGANIC CATIONS ON GROWTH AND TOXIN PRODUCTION BY CLOSTRIDIUM PERFRINGENS PB6K
}

\author{
RYOSUKE MURATA, SACHIKo SODA, AKIO YAMAMOTO \\ AND AKIHARU ITO \\ The 2nd Department of Bacteriology, National Institute of Health. Tokyo
}

(Received: November 6th, 1967)

\begin{abstract}
SUMMARY : Sodium ion and to a less extent potassium ion enhanced the growth and the syntheses of various toxic proteins of Clostridium perfringens PB6K. The optimum concentration of the total sodium and potassium ions was between $0.1 \mathrm{M}$ and $0.15 \mathrm{M}$. Autolysis of the organism was often observed when grown in a synthetic medium suitable for toxin production. Calcium prevented the autolysis without affecting the yield of alpha toxin. Although autolysis was inhibited by most of other divalent cations, they were harmful for the toxin production. A new synthetic medium was formulated.
\end{abstract}

\section{INTRODUCTION}

The previous reports (Murata and Yamamoto, 1964; Murata et al., 1965) indicated that a substrain derived from Clostridium perfringens PB6K produced fairly potent alpha toxin in a synthetic medium containing $L$-arginine at a high concentration. Unlike the results of the earlier works (Jayko and Lichstein, 1959; Tsukamoto, Yamamoto and Murata, 1963) no peptides were required for the production of alpha toxin under rigidly controlled cultural conditions. The organism grown in the synthetic medium was, however, prone to lyse at various stages of growth. It was apparent that the lysis occurred often in the medium containing phosphate at a high concentration. Shanker and Bard (1952) showed that various metallic ions affected the morphology and metabolic activities of $C$. perfringens, but they did not consider the problem of toxin production. It appeared to be of great interest to scrutinize the effects of inorganic ions on both growth and toxin production. The results of the experiments performed along this line have made it possible to elaborate a composition of the medium suitable for production of alpha toxin without vigorous autolysis.

\section{MATERIALS AND METHODS}

Strain, cultural methods and assay methods of growth and of alpha toxin: These were similar to those described in the previous paper (Murata et al., 1965) except for a few modifications.

1) Yeast extract (Daigo-Eiyo Co.) was added in a concentration of $0.5 \%$ to the seed medium consisting of the papain digest of beef and of fructose (Murata, Yamada

村田 良介・曾田 祥子・山本 昭夫・伊藤 明治 (国立予防衛生研究所細菌第二部) 
and Kameyama, 1956). The fructose concentration of the medium was $1 \%$, unless otherwise specified. This medium will be called "PYF medium" hereafter.

2) The synthetic medium described before (Murata et al., 1965) was used at the beginning of this study and called SM65 (Table 1). Vitamins and accessory growth factors were sterilized by filtration through a $0.27 \mu$ membrane filter (Grabar type No. 4, Toyo Roshi Co., Tokyo). The sterile mixture (see below) was kept at $-20 \mathrm{C}$ and added in a 0.2 $\mathrm{ml}$ amount to each tube $(10 \times 110 \mathrm{~mm})$ containing $4 \mathrm{ml}$ of otherwise complete medium. In this medium with $\mathrm{pH} 7.4 \sim 7.6$, potent toxin was produced. All the experiments were carried out in duplicate. One milliliter of the above mixture contained: $5 \mathrm{mg}$ L-glutamine, $20 \mu \mathrm{g}$ of $\mathrm{Ca} \mathrm{d}$-pantothenate, $20 \mu \mathrm{g}$ of nicotinic acid, $20 \mu \mathrm{g}$ of thiamine- $\mathrm{HCl}$, $14.2 \mu \mathrm{g}$ of of pyridoxamine- $2 \mathrm{HCl}, 10 \mu \mathrm{g}$ of riboflavine, $0.1 \mu \mathrm{g}$ of biotin, $340 \mu \mathrm{g}$ of adenine sulphate and $250 \mu \mathrm{g}$ of uracil. The mixture will be called "growth factor mixture".

Thble 1. Composition of the synthetic medium (SM65)

\begin{tabular}{|c|c|c|c|}
\hline Component & $\begin{array}{c}\text { Amount } \\
\text { per } 100 \mathrm{ml}\end{array}$ & Component & $\begin{array}{l}\text { Amount } \\
\text { per } 100 \mathrm{ml}\end{array}$ \\
\hline DL-Alanine & $50 \mathrm{mg}$ & Adenine sulphate & $1.7 \mathrm{mg}$ \\
\hline L-Arginine & $1000 \prime \prime$ & Uracil & $1.25 \prime \prime$ \\
\hline L-Asparagine & $50 \prime \prime$ & Ca d-pantothenate & $100 \mu \mathrm{g}$ \\
\hline L-Cystine & $5 \prime \prime$ & Nicotinic acid & $100 \prime \prime$ \\
\hline L-Glutamic acid & $75 \prime \prime$ & Thiamine- $\mathrm{HCl}$ & $100 \prime \prime$ \\
\hline L-Glutamine & $25 \prime \prime$ & Riboflavine & $50 \prime \prime$ \\
\hline Glycine & $50 \prime \prime$ & Pyridoxamine-2HCl & $71 \prime \prime$ \\
\hline L-Histidine & $25 \prime \prime$ & Biotin & $0.5 \prime \prime$ \\
\hline DL-Isoleucine & $50 \prime \prime$ & $\mathrm{Na}_{2} \mathrm{HPO}_{4}$ & $570 \mathrm{mg}$ \\
\hline L-Leucine & $35 \prime \prime$ & $\mathrm{KH}_{2} \mathrm{PO}_{4}$ & $140 " \prime$ \\
\hline L-Lysine & $25 \prime \prime$ & $\mathrm{MgSO}_{4} \cdot 7 \mathrm{H}_{2} \mathrm{O}$ & $20 \prime \prime$ \\
\hline DL-Methionine & $50 \prime \prime$ & $\mathrm{MnCl} \cdot 4 \mathrm{H}_{2} \mathrm{O}$ & $0.4 \prime \prime$ \\
\hline L-Proline & $15 \prime \prime$ & $\mathrm{ZnSO}_{4} \cdot 7 \mathrm{H}_{2} \mathrm{O}$ & $0.6 \prime \prime$ \\
\hline DL-Phenylalanine & $100 \prime \prime$ & $\mathrm{FeSO}_{4} \cdot 7 \mathrm{H}_{2} \mathrm{O}$ & $0.7 \prime \prime$ \\
\hline DL-Serine & $50 \prime \prime$ & Thioglycollic acid $(0.4 \%)$ & $2.5 \mathrm{ml}$ \\
\hline DL-Threonine & $50 \prime \prime$ & Fructose & $1 \mathrm{~g}$ \\
\hline L-Tryptophan & $25 \prime \prime$ & $\mathrm{pH}: \quad 7.4$ & \\
\hline L-Tyrosine & $10 \prime \prime$ & & \\
\hline DL-Valine & $25 \prime \prime$ & & \\
\hline
\end{tabular}

1) Solutions of iron, thioglycollic acid and fructose were autoclaved separately.

2) Glutamine, adenine, uracil and vitamins were sterilized by filtration (see the text).

3) Cultures were incubated at $37 \mathrm{C}$, instead of $35 \mathrm{C}$ as in the previous reports. Since cells often tended to lyse after $4 \mathrm{hr}$ incubation or later as illustrated by curve $\mathrm{b}$ in Fig. 1, the optical density of the culture was read hourly and the maximum value was recorded, unless otherwise stated. Alpha toxin was titrated usually only once after $6 \mathrm{hr}$ incubation, when the value reached the maximum irrespective of the status of lysis. Rarely the autolysis started soon after the beginning of growth and the optical density (OD) value remained at such a low level as 0.1-0.2. On such an occasion, 


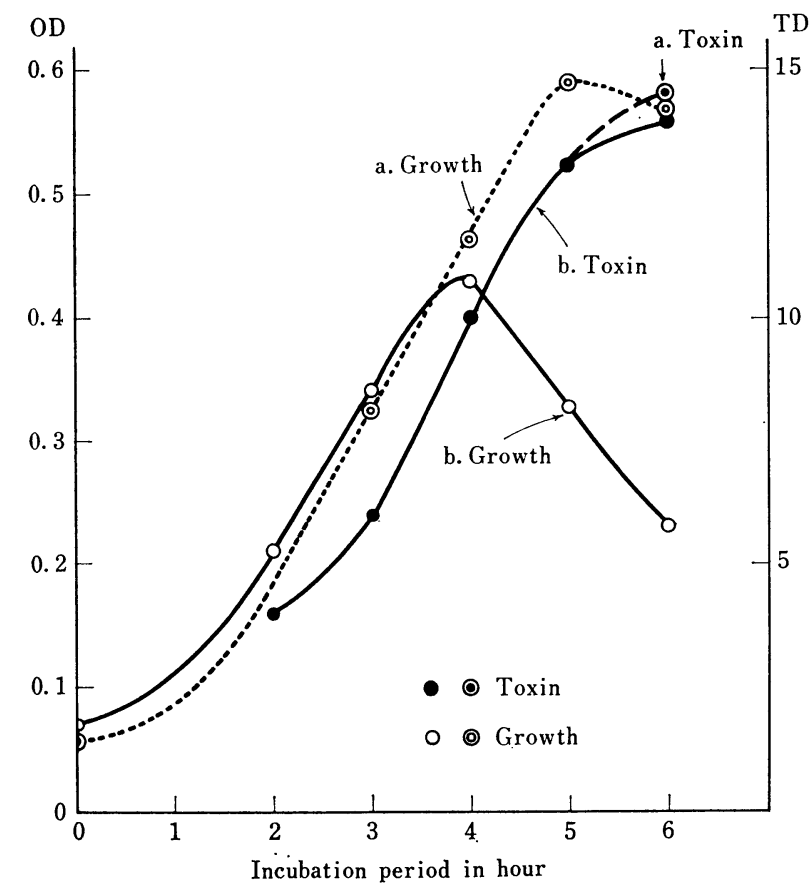

Fig. 1. Growth and toxin production in the synthetic medium (SM 65).

toxin yield was poor and the whole experiments were repeated with renewed seed cultures.

4) In some experiments, the phosphate concentration of SM65* was altered. A modified SM 65 was described as SM $65(a \mathrm{Ph})$ where $a$ shows the phosphate concentration in molarity, e. g., SM $65(\mathrm{M} / 200 \mathrm{Ph})$ in which the phosphate concentration of SM 65 was changed to $\mathrm{M} / 200$ without altering other components.

5) To estimate the toxin within the bacterial cells, they were washed well with chilled saline, resuspended, and disrupted by sonication at $10 \mathrm{kc}$ for $30 \mathrm{~min}$.

Assay of kappa and theta toxins: Kappa toxin was determined by the azocoll method established by Kameyama et al. (1968, to be published). The toxin titer was expressed in terms of the number of $\kappa$-unit per $\mathrm{ml}$. One $\kappa$-unit is an arbitrary unit of the toxin equivalent to the activity of a certain amount of the stable reference preparation of kappa toxin. Theta toxin was titrated by Pillemer's method modified by the authors as follows. Serial dilutions of test specimens in the diluent (see below) were let stand for $15 \mathrm{~min}$ at room temperature. One milliliter of each dilution was added with $1 \mathrm{ml}$ of a $1 \%$ sheep red cell suspension in the same diluent. The mixture was incubated for $30 \mathrm{~min}$ at $37 \mathrm{C}$. The titer of theta toxin was expressed in terms of the reciprocal of the highest dilution showing complete hemolysis under the conditions described above. One liter of the diluent contained: $5.39 \mathrm{~g}$ of $\mathrm{Na}_{2} \mathrm{HPO}_{4}, 4.99 \mathrm{~g}$ of $\mathrm{NaH}_{2} \mathrm{PO}_{4} \cdot 2 \mathrm{H}_{2} \mathrm{O}, 4.6 \mathrm{~g}$ of $\mathrm{NaCl}, 0.37 \mathrm{~g}$ of disodium ethylenediaminetetraacetate and $1.9 \mathrm{~g}$ of sodium thioglycollate. The last ingredient was added just before use.

\footnotetext{
* The phosphate concentration of SM65 was M/20.
} 
In the peptone medium (Murata et al., 1965) usually 20-30 $\kappa$-units, 2500-5000 $\theta$ units and 6-8 Lv per $\mathrm{ml}$ were produced.

Other methods: The cells were counted by a Petroff-Hausser Bacteria Counter. Viable number in the inoculum was counted as follows: One-tenth $\mathrm{ml}$ of an adequate dilution in saline of a bacterial suspension was spread evenly on a nutrient agar (Eiken Co., Tokyo) plate. This medium without blood supported a luxurient growth of $C$. perfringens in $24 \mathrm{hr}$. The plates were placed in an anaerobic jar containing the room temperature catalyst (Willis, 1964), incubated at $37 \mathrm{C}$ overnight and submitted to colony counting.

The amount of trichloroacetic acid (TCA)-insoluble nitrogen was determined by the semimicro-Kjeldahl method with the samples precipitated with $10 \%$ TCA and washed after having been kept overnight at cold. To estimate the cellular nitrogen, cells were washed well with chilled water and disrupted completely by sonication at $10 \mathrm{kc}$ for 30 $\min$.

\section{RESULTS}

\section{Effect of Sodium and Potassium Ions on the Growth and Toxin Production}

As suggested by Murata et al. (1965), the high concentration of phosphate required for the production of alpha toxin may have been due to the activity of cations. Experiments, therefore, aimed at investigating the effect of sodium and potassium ions on the growth and toxin production. A low-phosphate medium, SM65 (M/160 Ph), was selected as a basal medium, since growth was abundant but toxin production was rather poor in it (Murata et al., 1965). Various amounts of sodium chloride and potassium chloride were added to the basal medium to maintain the $\mathrm{Na}^{+} / \mathrm{K}^{+}$ratio at a constant level of $8: 1$.

As shown in Fig. 2, the OD value of the culture dropped sharply, while the yield of alpha toxin rose significantly as the salt concentration increased. The maximum yield of the toxin was obtained when the total $\mathrm{Na}^{+}+\mathrm{K}^{+}$concentration was between 0.1 and $0.15 \mathrm{M}$. Further increase in the salt concentration was harmful for both the growth and toxin production. No toxin was detectable within the cells grown in the basal medium when examined by the egg yolk method or by intravenous injection into mice.

Similar experiments were carried out with media with different phosphate concentrations, as shown in Table 2. Evidently, the concentration of the monovalent cations, not of phosphate, played an important role in promoting toxin production. The optimum concentration of the total $\mathrm{Na}^{+}+\mathrm{K}^{+}$for the toxin production was between 0.1 and $0.15 \mathrm{M}$, irrespective of the phosphate concentration. Another experiment disclosed that sodium nitrate could replace sodium chloride without significant reduction in the yield of toxin, though growth was slightly impaired.

In order to compare the activity of potassium ion and of sodium ion, various amounts of sodium chloride and of potassium chloride were added to the low-phosphate medium, SM $65(\mathrm{M} / 200 \mathrm{Ph})$, to vary the $\mathrm{Na}^{+} / \mathrm{K}^{+}$ratio maintaining $\mathrm{Na}^{+}+\mathrm{K}^{+}$concentration at a constant level of about $0.1 \mathrm{M}$. Table 3 indicates that though toxin was. produced over a wide range of $\mathrm{Na}^{+} / \mathrm{K}^{+}$ratio, excess of potassium ion retarded the growth, lowered the final $\mathrm{pH}$ and reduced the yield of toxin, while excess sodium ion 


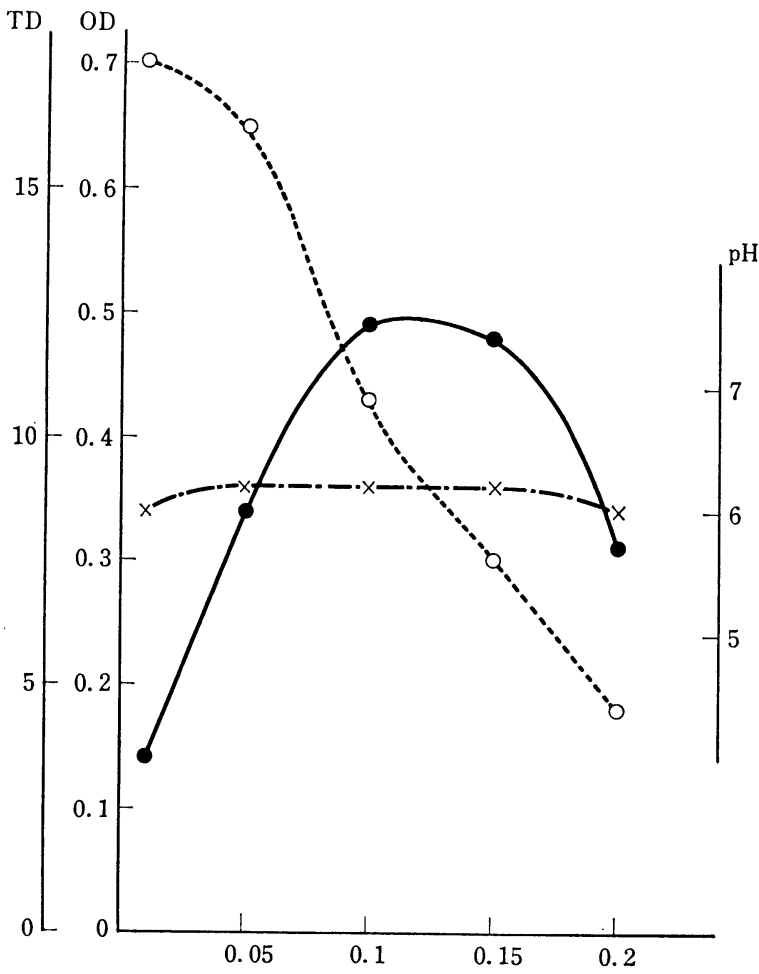

Total $\mathrm{Na}^{+}+\mathrm{K}^{+}$concentration in molarity

Fig. 2. Effect of the concentration of total $\mathrm{Na}^{+}+\mathrm{K}^{+}$on the growth and toxin production of $C$. perfringens.

- Toxin (TD/ml), O---O Growth (OD), $\times-\cdot-\cdot \times$ Final $\mathrm{pH}$ of the culture.

Table 2. Effect of the total concentratration of $\mathrm{Na}^{+}$and $\mathrm{K}^{+}$and phosphate on the growth and toxin production of $C$. perfringens

\begin{tabular}{|c|c|c|c|c|c|}
\hline \multirow{2}{*}{$\begin{array}{l}\text { Concentration } \\
\text { of phosphate }\end{array}$} & & \multicolumn{4}{|c|}{ Total concentration of $\mathrm{Na}^{+}$and $\mathrm{K}^{+}$} \\
\hline & & $0.05 \mathrm{M}$ & $0.10 \mathrm{M}$ & $0.15 \mathrm{M}$ & $0.20 \mathrm{M}$ \\
\hline \multirow{2}{*}{$\mathrm{M} / 160$} & $\int$ Toxin $(\mathrm{TD} / \mathrm{ml})$ & 8 & 12 & 12 & 8 \\
\hline & Growth & 0.65 & 0.42 & 0.30 & 0.18 \\
\hline \multirow{2}{*}{$\mathrm{M} / 80$} & $\int$ Toxin $(\mathrm{TD} / \mathrm{ml})$ & 10 & 14 & 13 & 9 \\
\hline & \{ Growth & 0.62 & 0.44 & 0.34 & 0.20 \\
\hline \multirow{2}{*}{$\mathrm{M} / 40$} & $\{$ Toxin $(\mathrm{TD} / \mathrm{ml})$ & 9 & 15 & 15 & 11 \\
\hline & Growth & 0.59 & 0.48 & 0.36 & 0.25 \\
\hline \multirow{2}{*}{$\mathrm{M} / 20$} & $\{$ Toxin $(\mathrm{TD} / \mathrm{ml})$ & - & 14 & 14 & 10 \\
\hline & Growth & - & 0.55 & 0.41 & 0.21 \\
\hline
\end{tabular}

Figures are means of three separate experiments each of which was carried out in duplicate. 
was not unfavorable in any respect. Though potassium ion was an indispensable component, its minimum requirement was small. A concentration of no higher than 0.01 $\mathrm{M}$ was enough for both the growth and toxin production provided that the total $\mathrm{Na}^{+}$ $+\mathrm{K}^{+}$concentration was kept at $0.1 \mathrm{M}$ to $0.15 \mathrm{M}$ with sodium chloride.

Table 3. Effect of the $\mathrm{Na}^{+} / \mathrm{K}^{+}$ratio on the growth and toxin production of $C$. perfringens

\begin{tabular}{|c|c|c|c|c|c|c|c|}
\hline \multirow{2}{*}{$\mathrm{Na}^{+}:$} & \multirow{2}{*}{$: \mathrm{K}^{+}$} & \multicolumn{3}{|c|}{ Growth after } & \multicolumn{2}{|c|}{ Toxin } & \multirow{2}{*}{ Final $\mathrm{pH}$} \\
\hline & & $4 \mathrm{hr}$ & $5 \mathrm{hr}$ & $6 \mathrm{hr}$ & $\mathrm{TD} / \mathrm{ml}$ & $\mathrm{EU} / \mathrm{ml}$ & \\
\hline 99 & $: 1$ & 0.41 & 0.56 & 0.44 & 11 & 34 & 6.2 \\
\hline 16 & $: 1$ & 0.48 & 0.57 & 0.51 & 12 & 35 & 6.2 \\
\hline 8 & $: 1$ & 0.46 & 0.61 & 0.56 & 11 & 34 & 6.2 \\
\hline 3.7 & $: 1$ & 0.45 & 0.58 & 0.52 & 11 & 28 & 6.2 \\
\hline 2.2 & $: 1$ & 0.46 & 0.52 & 0.52 & 12 & 39 & 6.2 \\
\hline 1 & $: 1$ & 0.43 & 0.62 & 0.57 & 10 & 31 & 6.2 \\
\hline 1 & $: 4.5$ & 0.43 & 0.54 & 0.49 & 5 & 21 & 5.8 \\
\hline 1 & $: \quad 6.7$ & 0.41 & 0.52 & 0.43 & 3.5 & 17 & 5.7 \\
\hline 1 & : 11.5 & 0.30 & 0.46 & 0.54 & 1.5 & 9 & 5.4 \\
\hline
\end{tabular}

1) Basal medium: $\mathrm{SM} 65(\mathrm{M} / 200 \mathrm{Ph})$.

2) $\mathrm{NaCl}$ and $\mathrm{KCl}$ were added to the basal medium in various amounts, keeping the total $\mathrm{Na}^{+}$and $\mathrm{K}^{+}$concentration at a constant level of $0.1 \mathrm{M}$.

The poor growth apparent in high-salt media may have been due to the autolysis during the early stage of growth. This was confirmed as illustrated in Fig. 3 by hourly determinations of the optical density. The higher the salt concentration, the more marked was the autolysis, and such a tendency was more pronounced in lowphosphate media.

\section{The Importance of the Buffer Action of the Medium for Toxin Production}

The effect of monovalent cations on the toxin production in low-phosphate media was marked but the results fluctuated depending on each experiment, probably due to the different extents of acid production. The yield of alpha toxin was usually poor when the final $\mathrm{pH}$ was lower than 6.0. When acid production was vigorous, not only the yield of toxin but also the growth was significantly poorer in a low-phosphate medium such as SM65 $(\mathrm{M} / 200 \mathrm{Ph})$ than those in well-buffered one even when the former was enriched with sodium and potassium ions. When acid production was abundant, the growth and toxin production in low-phosphate media were enhanced if the buffer action of the medium was strengthened with sodium bicarbonate, as shown in Table 4.

\section{Effect of the Monovalent Cations on the Production of Various Toxic Proteins}

It was planned to see whether the monovalent cations stimulate the production of other toxic proteins. Experiments were carried out in $16 \times 165 \mathrm{~mm}$ test tubes contain- 


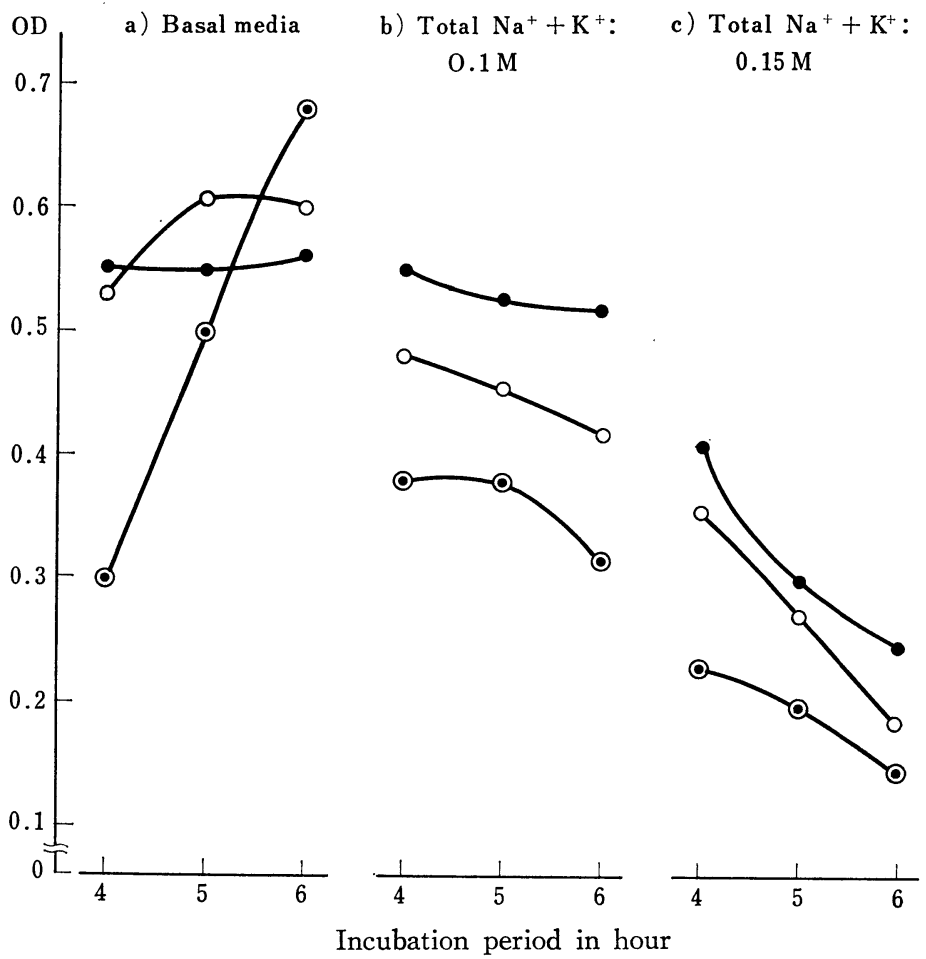

Fig. 3. Effect of the concentration of phosphate and total $\mathrm{Na}^{+}+\mathrm{K}^{+}$ on the growth of $C$. perfringens.

- $\mathrm{SM} 65, \mathrm{O} \longrightarrow \mathrm{O} \mathrm{SM} 65(\mathrm{M} / 40, \mathrm{Ph})$,

$\mathrm{SM} 65(\mathrm{M} /$ 160, $\mathrm{Ph}$ ). Total $\mathrm{Na}^{+}+\mathrm{K}^{+}$concentration of the basal media was 0.09 , 0.045 and 0.01125 respectively.

Table 4. Effect of $\mathrm{NaHCO}_{3}$ on the growth and toxin production of $C$. perfringens

\begin{tabular}{|c|c|c|c|c|c|c|}
\hline \multirow{2}{*}{ Medium* } & \multirow{2}{*}{$\begin{array}{l}\text { Total concentration } \\
\text { of } \mathrm{Na}^{+} \text {and } \mathrm{K}^{+} \\
\text {in molarity }\end{array}$} & \multicolumn{3}{|c|}{ Growth after } & \multirow{2}{*}{$\begin{array}{l}\text { Toxin } \\
\text { (TD/ml) }\end{array}$} & \multirow{2}{*}{ Final $\mathrm{pH}$} \\
\hline & & $4 \mathrm{hr}$ & $5 \mathrm{hr}$ & $6 \mathrm{hr}$ & & \\
\hline SM65 & 0.09 & 0.45 & 0.48 & 0.43 & 10 & 6.2 \\
\hline $\mathrm{SM} 65(\mathrm{M} / 200 \mathrm{Ph})$ & 0.009 & 0.24 & 0.32 & 0.39 & 2 & 5.4 \\
\hline $\begin{array}{l}\mathrm{SM} 65(\mathrm{M} / 200 \mathrm{Ph}) \\
\text { supplemented with } \\
\mathrm{NaCl} \text { and } \mathrm{KCl}\end{array}$ & 0.10 & 0.31 & 0.38 & 0.44 & 2 & 5.4 \\
\hline \multirow{5}{*}{$\begin{array}{l}\mathrm{SM} 65(\mathrm{M} / 200 \mathrm{Ph}) \\
\text { supplemented with } \\
\mathrm{NaHCO}_{3} \text { and } \mathrm{KCl}\end{array}$} & 0.05 & 0.50 & 0.61 & 0.56 & 10 & 6.3 \\
\hline & 0.10 & 0.48 & 0.45 & 0.39 & 10 & 6.2 \\
\hline & 0.125 & 0.38 & 0.38 & 0.28 & 10 & 6.2 \\
\hline & 0.15 & 0.36 & 0.35 & 0.24 & 8 & 6.2 \\
\hline & 0.20 & 0.31 & 0.27 & 0.16 & 5 & 6.4 \\
\hline
\end{tabular}

* $\mathrm{NaCl}$ (or $\mathrm{NaHCO}_{3}$ ) and $\mathrm{KCl}$ were added to make the $\mathrm{Na}^{+} / \mathrm{K}^{+}$ratio $8: 1$. 
ing $10 \mathrm{ml}$ of media. Table 5 shows that the addition of the cations promoted the production of different toxins as well as the synthesis of bacterial protein in general. A better yield of alpha toxin in medium (3) may have resulted from its strong buffer action.

Table 5. Effect of sodium and potassium ions on the production of various toxins

\begin{tabular}{|c|c|c|c|c|c|c|c|c|c|c|}
\hline \multirow{2}{*}{ Medium } & \multicolumn{3}{|c|}{ Toxins $^{2)}$} & \multirow{2}{*}{$\begin{array}{c}\text { Final } \\
\mathrm{pH}^{2)}\end{array}$} & \multicolumn{2}{|c|}{ Growth $^{3)}$ after } & \multicolumn{3}{|c|}{$\begin{array}{c}\text { TCA-insoluble } \\
\text { nitrogen }(\mathrm{mg} / \mathrm{ml})^{2)}\end{array}$} & \multirow{2}{*}{$\begin{array}{l}\text { Protein } \\
\text { synthe- } \\
\text { sized } \\
(\mathrm{mg} / \mathrm{ml}) \\
\end{array}$} \\
\hline & $\begin{array}{c}\alpha \\
(\mathrm{TD} / \mathrm{ml})\end{array}$ & $\kappa$ & $\theta$ & & $4 \mathrm{hr}$ & $6 \mathrm{hr}$ & Cell & $\begin{array}{l}\text { Super- } \\
\text { natant }\end{array}$ & Total & \\
\hline $\begin{array}{l}\text { (1) Basal medium } \\
\text { SM65 }(\mathrm{M} / 200 \mathrm{Ph})\end{array}$ & 2 & 6 & $1: 320$ & 5.6 & 0.59 & 0.81 & 0.07 & 0.03 & 0.10 & 0.625 \\
\hline $\begin{array}{l}\text { (2) } \mathrm{BM} \text { enriched } \\
\text { with }^{1)}: \\
\mathrm{NaCl} 0.08 \mathrm{M} \\
\mathrm{KCl} 0.01 \mathrm{M}\end{array}$ & 8 & 12 & $1: 1280$ & 5.8 & 0.56 & 0.73 & 0.12 & 0.06 & 0.18 & 1.12 \\
\hline $\begin{array}{l}\text { (3) } \mathrm{BM} \text { enriched } \\
\text { with' } \\
\mathrm{NaCl} 0.05 \mathrm{M} \\
\mathrm{KCl} 0.01 \mathrm{M} \\
\mathrm{NaHCO}_{3} 0.02 \mathrm{M}\end{array}$ & 14 & 10 & $1: 1280$ & 7.2 & 0.70 & 0.73 & 0.10 & 0.06 & 0.16 & 1.106 \\
\hline
\end{tabular}

1) The total $\mathrm{Na}^{+}$and $\mathrm{K}^{+}$concentrations in media (2) and (3) were $0.1 \mathrm{M}$ and $0.09 \mathrm{M}$, respectively, and the $\mathrm{Na}^{+} / \mathrm{K}^{+}$ratio was $8: 1$.

2) Determined after $6 \mathrm{hr}$ incubation.

3) The OD values were determined at the light path of $16 \mathrm{~mm}$.

4) Calculated from TCA-insoluble nitrogen.

\section{Effect of Divalent Cations on the Growth and Toxin Production}

It is of great interest to see whether divalent cations have the activity similar to that of the monovalent ones stated above. Various amounts of divalent cations that had been reported to be necessary for growth were added to the low-phosphate medium SM $65(\mathrm{M} / 200 \mathrm{Ph})$, as shown in Table 6 . In contrast to monovalent cations, toxin production was not promoted but rather inhibited when the concentration of the divalent cations in the medium was increased. Generally, the final $\mathrm{pH}$ became lower as the amount of the cations increased.

Since divalent cations have been reported to have a stabilizing effect for the membrane structure of bacteria (Brown, 1964; Razin, 1965), experiments were performed to see whether they inhibit the autolysis of the organism grown in a medium suitable for toxin production. In such an experiment a low phosphate medium supplemented with the monovalent cations and buffering reagents was suitable because the organisms tended to lyse in this medium (see Fig. 3). Table 7 shows that various divalent cations prevented the autolysis, though most of them were harmful for toxin production with the exception of calcium. The optimum concentration of calcium to prevent the autolysis was about $0.5 \mathrm{mM}$, as illustrated in Fig. 4. Then we scrutinized the effect of calcium on the growth as well as on the protein synthesis. Three media shown in Table 8 were used. Experiments were carried out with $300 \mathrm{ml}$ Erlenmeyer flasks each dispensed with $200 \mathrm{ml}$ of medium. The amount of the inoculum was adjusted so as to obtain the maximum growth after $6 \mathrm{hr}$ incubation. Table 8 clearly demonstrates that calcium prevented the autolysis without any harmful effect on the growth and production of various toxins. 
Table 6. Effects of various divalent cations on the growth and toxin production in a low-phosphate medium

\begin{tabular}{|c|c|c|c|c|c|}
\hline Experiment & Medium & $\begin{array}{l}\text { Concentration } \\
\text { of the divalent } \\
\text { cation increased }\end{array}$ & Growth & Toxin $(\mathrm{TD} / \mathrm{ml})$ & Final $\mathrm{pH}$ \\
\hline \multirow{4}{*}{ I } & Basal medium ${ }^{1)}$ & 2) & 0.61 & 2 & 5.9 \\
\hline & $\mathrm{Mg}^{2+}$ increased & $\begin{array}{r}4 \mathrm{mM} \\
8 \mathrm{mM} \\
20 \mathrm{mM} \\
40 \mathrm{mM}\end{array}$ & $\begin{array}{l}0.61 \\
0.57 \\
0.57 \\
0.51\end{array}$ & $\begin{array}{r}2 \\
2 \\
<2 \\
<2\end{array}$ & $\begin{array}{l}5.9 \\
5.8 \\
5.7 \\
5.6\end{array}$ \\
\hline & $\mathrm{Fe}^{2+}$ increased & $\begin{array}{l}0.05 \mathrm{mM} \\
0.125 \mathrm{mM} \\
0.25 \mathrm{mM}\end{array}$ & $\begin{array}{l}0.58 \\
0.57 \\
0.44\end{array}$ & $\begin{array}{l}<2 \\
<2 \\
<2\end{array}$ & $\begin{array}{l}5.8 \\
5.6 \\
5.2\end{array}$ \\
\hline & $\mathrm{BM}+\mathrm{NaCl}+\mathrm{KCl}^{3)}$ & 2) & 0.43 & 10 & 6.0 \\
\hline \multirow{4}{*}{ II } & Basal medium ${ }^{1)}$ & 2) & 0.32 & 0 & 5.4 \\
\hline & $\mathrm{Zn}^{2+}$ increased & $\begin{array}{l}0.048 \mathrm{mM} \\
0.12 \mathrm{mM} \\
0.24 \mathrm{mM}\end{array}$ & $\begin{array}{l}0.31 \\
0.31 \\
0.32\end{array}$ & $\begin{array}{l}0 \\
0 \\
0\end{array}$ & $\begin{array}{l}5.4 \\
5.4 \\
5.4\end{array}$ \\
\hline & $\mathrm{BM}+\mathrm{NaCl}+\mathrm{KCl}^{3)}$ & 2) & 0.57 & 7 & 6.0 \\
\hline & $\begin{array}{l}\text { Above with } \\
\text { increased } \mathrm{Zn}^{2+}\end{array}$ & $\begin{array}{l}0.12 \mathrm{mM} \\
0.24 \mathrm{mM}\end{array}$ & $\begin{array}{l}0.59 \\
0.53\end{array}$ & $\begin{array}{r}3 \\
\ll 2\end{array}$ & $\begin{array}{l}5.8 \\
5.4\end{array}$ \\
\hline
\end{tabular}

1) Basal medium: $\operatorname{SM} 65(\mathrm{M} / 200 \mathrm{Ph})$.

2) The concentration of $\mathrm{Mg}^{2+}, \mathrm{Fe}^{2+}$ or $\mathrm{Zn}^{2+}$ in the basal medium was $0.8 \mathrm{mM}, 0.025 \mathrm{mM}$ or $0.024 \mathrm{mM}$, respectively.

3) $\mathrm{NaCl}$ and $\mathrm{KCl}$ were added so that the total $\mathrm{Na}^{+}$and $\mathrm{K}^{+}$concentration and $\mathrm{Na}^{+} / \mathrm{K}^{+}$ ratio became $0.1 \mathrm{M}$ and $8: 1$, respectively.

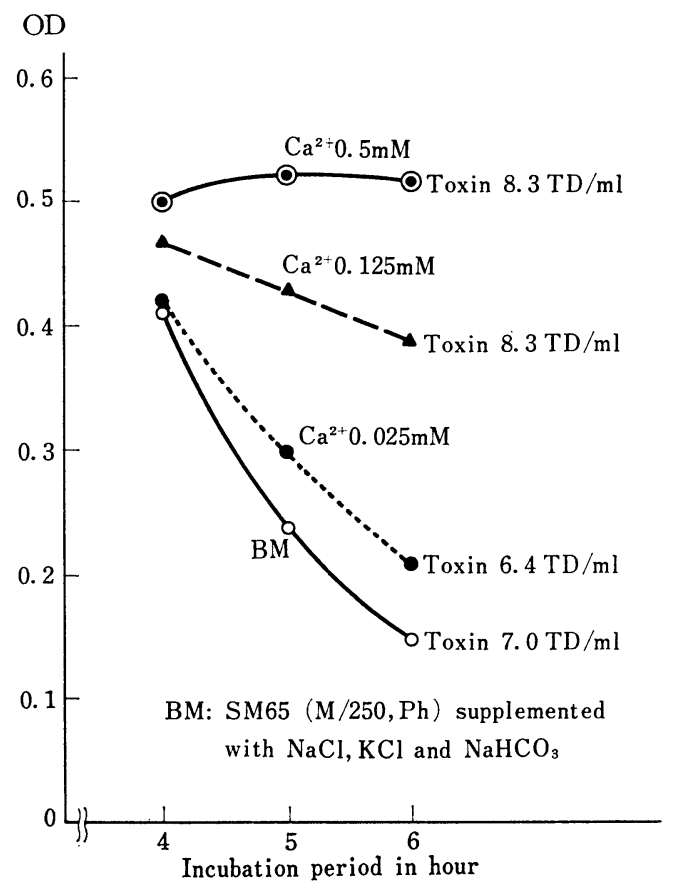

Fig. 4. Effect of $\mathrm{Ca}^{2+}$ on the growth of $C$. perfringens. 
Table 7. Effect of divalent cations on the autolysis of $C$. perfringens

\begin{tabular}{|c|c|c|c|c|c|c|}
\hline \multirow{2}{*}{ Experiment } & \multirow{2}{*}{\multicolumn{2}{|c|}{$\begin{array}{l}\text { Divalent ions } \\
\text { added to the } \\
\text { basal medium }{ }^{1)}\end{array}$}} & \multicolumn{2}{|c|}{ Growth after } & \multirow{2}{*}{$\underset{(\mathrm{TD} / \mathrm{ml})}{\text { Toxin }}$} & \multirow{2}{*}{ Final $\mathrm{pH}$} \\
\hline & & & $4 \mathrm{hr}$ & $6 \mathrm{hr}$ & & \\
\hline \multirow{5}{*}{ I } & \multicolumn{2}{|l|}{ None } & 0.48 & 0.18 & 6 & 6.0 \\
\hline & \multicolumn{2}{|c|}{$\begin{array}{ll}\mathrm{Co}^{2+} & 0.017 \mathrm{mM} \\
0.34 \mathrm{mM}\end{array}$} & $\begin{array}{l}0.49 \\
0.50\end{array}$ & $\begin{array}{l}0.60 \\
0.57\end{array}$ & $\begin{array}{r}3 \\
<2\end{array}$ & $\begin{array}{l}6.1 \\
6.1\end{array}$ \\
\hline & \multicolumn{2}{|c|}{$\begin{array}{ll}\mathrm{Cu}^{2+} & 0.016 \mathrm{mM} \\
& 0.32 \mathrm{mM}\end{array}$} & $\begin{array}{l}0.46 \\
0.53\end{array}$ & $\begin{array}{l}0.40 \\
0.69\end{array}$ & $\begin{array}{r}2 \\
<2\end{array}$ & $\begin{array}{l}6.2 \\
6.3\end{array}$ \\
\hline & \multicolumn{2}{|c|}{$\begin{array}{ll}\mathrm{Ni}^{2+} & 0.017 \mathrm{mM} \\
0.34 \mathrm{mM}\end{array}$} & $\begin{array}{l}0.55 \\
0.53\end{array}$ & $\begin{array}{l}0.43 \\
0.37\end{array}$ & $\begin{array}{l}5 \\
5\end{array}$ & $\begin{array}{l}6.3 \\
6.2\end{array}$ \\
\hline & \multicolumn{2}{|c|}{$\mathrm{Ca}^{2+} 0.5 \mathrm{mM}$} & 0.64 & 0.61 & 7 & 6.3 \\
\hline \multirow{3}{*}{ II } & \multicolumn{2}{|c|}{ None ${ }^{2)}$} & 0.41 & 0.13 & 5 & 6.2 \\
\hline & \multicolumn{2}{|c|}{$\begin{array}{ll}\mathrm{Fe}^{2+} & 0.075 \mathrm{mM}^{3)} \\
& 0.25 \mathrm{mM}^{3)}\end{array}$} & $\begin{array}{l}0.40 \\
0.42\end{array}$ & $\begin{array}{l}0.20 \\
0.57\end{array}$ & $\begin{array}{l}5 \\
2\end{array}$ & $\begin{array}{l}6.4 \\
6.1\end{array}$ \\
\hline & \multicolumn{2}{|c|}{$\mathrm{Ca}^{2+} \quad 0.5 \mathrm{mM}$} & 0.54 & 0.56 & 10 & 6.4 \\
\hline \multirow{4}{*}{ III } & \multicolumn{2}{|c|}{ None ${ }^{2)}$} & 0.24 & 0.06 & 7 & 6.2 \\
\hline & \multicolumn{2}{|c|}{$\begin{array}{ll}\mathrm{Zn}^{2+} & 0.072 \mathrm{mM}^{3)} \\
& 0.24 \mathrm{mM}^{3)}\end{array}$} & $\begin{array}{l}0.28 \\
0.31\end{array}$ & $\begin{array}{l}0.06 \\
0.08\end{array}$ & $\begin{array}{l}5 \\
2\end{array}$ & $\begin{array}{l}6.2 \\
6.1\end{array}$ \\
\hline & \multicolumn{2}{|c|}{$\mathrm{Mg}^{2+} \begin{array}{ll}2.4 & \mathrm{mM}^{3)} \\
8.0 & \mathrm{mM}^{3)}\end{array}$} & $\begin{array}{l}0.39 \\
0.47\end{array}$ & $\begin{array}{l}0.09 \\
0.31\end{array}$ & $\begin{array}{l}7 \\
8\end{array}$ & $\begin{array}{l}6.2 \\
6.2\end{array}$ \\
\hline & $\mathrm{Ca}^{2+}$ & $0.5 \mathrm{mM}$ & 0.42 & 0.26 & 11 & 6.4 \\
\hline
\end{tabular}

1) Basal medium: SM65 $(\mathrm{M} / 250 \mathrm{Ph})$ supplemented with $\mathrm{NaCl}, \mathrm{NaHCO}_{3}$ and $\mathrm{KCl}$ so that the total $\mathrm{Na}^{+}$and $\mathrm{K}^{+}$concentration would be $0.1 \mathrm{M}$ and the $\mathrm{Na}^{+} / \mathrm{K}^{+}$ratio $8: 1$.

2) The concentrations of $\mathrm{Fe}^{2+}, \mathrm{Zn}^{2+}$ or $\mathrm{Mg}^{2+}$ in the basal medium were $0.025 \mathrm{mM}, 0.024$ $\mathrm{mM}$ and $0.8 \mathrm{mM}$, respectively.

3) Figures show the total concentration of the cation in the medium.

Table 8. Effect of calcium on the growth and toxin production

\begin{tabular}{|c|c|c|c|c|c|c|c|c|c|c|c|}
\hline \multirow[t]{2}{*}{ Medium } & \multicolumn{2}{|c|}{$\begin{array}{l}\text { Growth } \\
\text { after }\end{array}$} & \multirow{2}{*}{$\begin{array}{c}\begin{array}{c}\text { Final } \\
\mathrm{pH}\end{array} \\
6 \mathrm{hr}\end{array}$} & \multicolumn{2}{|c|}{$\begin{array}{l}\text { Number of } \\
\text { bacteria per } \\
\text { ml }\left(\times 10^{6}\right) \\
\end{array}$} & \multicolumn{3}{|c|}{$\begin{array}{c}\text { TCA-insoluble } \\
\text { nitrogen }^{2} \text { (mg/ml) }\end{array}$} & \multicolumn{3}{|c|}{ Toxins ${ }^{2)}$} \\
\hline & $4 \mathrm{hr}$ & $6 \mathrm{hr}$ & & $4 \mathrm{hr}$ & $6 \mathrm{hr}$ & Cell & $\begin{array}{l}\text { Super- } \\
\text { natant }\end{array}$ & Total & $\begin{array}{c}\alpha \\
(\mathrm{TD} / \mathrm{ml})\end{array}$ & $\kappa$ & $\theta$ \\
\hline $\begin{array}{l}\text { (1) Basal Medium } \\
\text { SM65 (M/200 Ph) }\end{array}$ & 0.24 & 0.36 & 5.4 & 310 & 580 & 0.07 & 0.006 & 0.076 & $\ll 2$ & $\ll 1$ & $1: 160$ \\
\hline $\begin{array}{l}\text { (2) } \mathrm{BM} \text { enriched }{ }^{1)} \\
\text { with } \mathrm{NaCl} \\
\mathrm{NaHCO} \mathrm{CO}_{3} \text { and } \\
\mathrm{KCl}\end{array}$ & 0.38 & 0.22 & 7.2 & 590 & 160 & 0.05 & 0.16 & 0.21 & 7 & 8 & $1: 2560$ \\
\hline $\begin{array}{l}\text { (3) Medium (2) } \\
\text { added with } \\
\mathrm{CaCl}_{2}(0.5 \mathrm{mM})\end{array}$ & 0.45 & 0.43 & 7.2 & 650 & 480 & 0.07 & 0.09 & 0.16 & 17 & 30 & $1: 2560$ \\
\hline
\end{tabular}

1) As regards the concentration of the monovalent cations, refer to the footnote of Table 7.

2) Determined after $6 \mathrm{hr}$ incubation. 


\section{New Medium for Toxin Production}

Since metallic ions have critical effects on both the growth and toxin production, the constituents of SM65 were reinvestigated by altering the concentration of each inorganic compound and by supplementing some additional compounds and a new formula of synthetic medium was elaborated, as shown in Table 9. All ingredients except for those asterisked were dissolved in water in an amount equivalent to $85 \%$ of the expected volume. The $\mathrm{pH}$ was adjusted to 7.4-7.6. A $3.4 \mathrm{ml}$ amount of the solution was distributed into each tube $(10 \times 110 \mathrm{~mm})$ and autoclaved. After cooling, each tube was added with $0.2 \mathrm{ml}$ of the growth factor mixture, $0.2 \mathrm{ml}$ of the iron-sugar-buffer mixture, $0.1 \mathrm{ml}$ of a $0.4 \%$ thioglycollic acid and $0.1 \mathrm{ml}$ of the inoculum.

Table 9. Composition of SM67, a new medium

\begin{tabular}{|c|c|c|c|c|c|}
\hline \multirow{2}{*}{$\begin{array}{r}\text { Component } \\
\text { DL-Alanine }\end{array}$} & \multicolumn{2}{|c|}{$\begin{array}{l}\text { Amount } \\
\text { per } 100 \mathrm{ml}\end{array}$} & \multirow{2}{*}{$\begin{array}{c}\text { Component } \\
\text { Ca d-pantothenate* }\end{array}$} & \multicolumn{2}{|c|}{$\begin{array}{c}\text { Amount } \\
\text { per } 100 \mathrm{ml}\end{array}$} \\
\hline & 50 & $\mathrm{mg}$ & & 100 & $\mu \mathrm{g}$ \\
\hline L-Arginine & 1000 & $\prime \prime$ & Nicotinic acid* & 100 & " \\
\hline L-Asparagine & 50 & "I & Thiamine- $\mathrm{HCl}^{*}$ & 100 & "1 \\
\hline L-Cystine & 5 & $\prime \prime$ & Pyridoxamine-2 $\mathrm{HCl}^{*}$ & 71 & " \\
\hline L-Glutamic acid & 75 & $\prime \prime$ & Riboflavine* & 50 & " \\
\hline L-Glutamine* & 25 & $\prime \prime$ & Biotin* & 0.5 & $\prime \prime$ \\
\hline Glycine & 50 & $\prime \prime$ & & & \\
\hline L-Histidine & 25 & '1 & $\mathrm{Na}_{2} \mathrm{HPO}_{4}$ & 230 & $\mathrm{mg}$ \\
\hline DL-Isoleucine & 50 & $\prime \prime$ & $\mathrm{NaHCO}_{3} *$ & 170 & " \\
\hline L-Leucine & 35 & $\prime \prime$ & $\mathrm{NaCl}$ & 300 & $\prime \prime$ \\
\hline L-Lysine & 25 & $\prime \prime$ & $\mathrm{KCl}$ & 80 & " \\
\hline DL-Methionine & 50 & $\prime \prime$ & $\mathrm{MgSO}_{4} \cdot 7 \mathrm{H}_{2} \mathrm{O}$ & 20 & " \\
\hline L-Proline & 15 & $\prime \prime$ & $\mathrm{CaCl}_{2} \cdot 2 \mathrm{H}_{2} \mathrm{O}$ & 7.4 & 11 \\
\hline DL-Phenylalanine & 100 & $\prime \prime$ & $\mathrm{ZnSO}_{4} \cdot 7 \mathrm{H}_{2} \mathrm{O}$ & 1.4 & $=11$ \\
\hline DL-Serine & 50 & $\prime \prime$ & $\mathrm{MnCl}_{2} \cdot 4 \mathrm{H}_{2} \mathrm{O}$ & 0.5 & 11 \\
\hline DL-Threonine & 50 & $\prime \prime$ & $\mathrm{FeSO}_{4} \cdot 7 \mathrm{H}_{2} \mathrm{O}^{*}$ & 0.7 & $\prime \prime$ \\
\hline L-Tryptophan & 25 & $\prime \prime$ & & & \\
\hline L-Tyrosine & 10 & $\prime \prime$ & Fructose* & 1.0 & $\mathrm{~g}$ \\
\hline DL-Valine & 25 & $\prime \prime$ & Thioglycollic acid $(0.4 \%)^{*}$ & & $\mathrm{ml}$ \\
\hline Adenine sulphate* & & $\prime \prime$ & $\mathrm{pH} \quad:$ & $7.4 \mathrm{t}$ & to 7.6 \\
\hline Uracil* & & & & & \\
\hline
\end{tabular}

* These components were sterilized separately as follows :

1) Solutions of iron, fructose and thioglycollic acid were autoclaved separately.

2) Crystals of $\mathrm{NaHCO}_{3}$ were autoclaved in a test tube and dissolved by adding autoclaved fructose solution to a desired concentration and then added with the sterile iron solution (ion-sugar-buffer mixture).

3) Glutamine, adenine, uracil and vitamins were sterilized by filtration as shown in Materials and Methods (growth factor mixture).

Table 10 shows that this new medium (called SM67) is superior to SM65 in many respects. Since the autolysis was prevented, it became possible to transfer the strain successively in the same medium. One loopful of the culture was sufficient to give 
Table 10. Comparison of growth and toxin production in two synthetic media

\begin{tabular}{|c|c|c|c|c|c|c|c|c|c|}
\hline \multirow{3}{*}{$\begin{array}{c}\text { Experi- } \\
\text { ment }\end{array}$} & \multirow{3}{*}{ Strain $^{1,2,3)}$} & \multicolumn{4}{|c|}{ Medium 1967 (SM67) } & \multicolumn{4}{|c|}{ Medium 1965 (SM65) } \\
\hline & & \multicolumn{2}{|c|}{ Growth after } & \multirow{2}{*}{$\begin{array}{l}\text { Toxin } \\
\text { (TD } / \mathrm{ml})\end{array}$} & \multirow{2}{*}{$\begin{array}{c}\text { Final } \\
\mathrm{pH}\end{array}$} & \multicolumn{2}{|c|}{ Growth after } & \multirow{2}{*}{$\begin{array}{l}\text { Toxin } \\
(\mathrm{TD} / \mathrm{ml})\end{array}$} & \multirow{2}{*}{$\begin{array}{c}\text { Final } \\
\mathrm{pH}\end{array}$} \\
\hline & & $4 \mathrm{hr}$ & $6 \mathrm{hr}$ & & & $4 \mathrm{hr}$ & $6 \mathrm{hr}$ & & \\
\hline \multirow[t]{2}{*}{ I } & N5P67(1.0) & 0.54 & 0.60 & 22 & 7.2 & 0.30 & 0.32 & 14 & 6.0 \\
\hline & N5P $67(1.0)$ & 0.38 & 0.46 & 10 & 6.4 & 0.14 & 0.05 & 5 & 6.0 \\
\hline \multirow[t]{3}{*}{ II } & N5P67(0.2) & 0.40 & 0.56 & 10 & 6.4 & 0.14 & 0.09 & 5 & 6.0 \\
\hline & N5P67( 0$)$ & 0.40 & 0.60 & 12 & 6.4 & 0.12 & 0.06 & 5 & 6.2 \\
\hline & N5P $67(0.2)$ & 0.40 & 0.54 & 8 & 6.6 & 0.15 & 0.06 & 4 & 6.1 \\
\hline \multirow[t]{2}{*}{ III } & L $4(0.2)$ & 0.72 & 0.69 & 14 & 6.4 & 0.40 & 0.32 & 10 & 6.2 \\
\hline & L 5 (0.2) & 0.73 & 0.76 & 17 & 6.4 & 0.65 & 0.64 & 8 & 6.2 \\
\hline
\end{tabular}

1) N5P67 was obtained from $C$. perfringens $\mathrm{PB} 6 \mathrm{~K}$ N5 strain by three successive pigeon passages carried out by the method described by Logan et al., (1945). The strain was prone to lyse in SM65 after several transfers in PYF medium.

2) L4 and L5 were the lyophilized strains from subcultures of N5 maintained in the synthetic medium SM67. The strains were used after two transfers in the PYF seed medium.

3) Figures in the parentheses show the sugar concentration of PYF seed medium in percent.

luxurient growth in the new medium. With such a small inoculum, the maximum growth was obtained in 10 to $12 \mathrm{hr}$ and the yield of alpha toxin was comparable to the culture seeded with a large inoculum and harvested after $6 \mathrm{hr}$ of incubation, as shown in Table 11. It was also observed that the level of toxin produced during the active growth was maintained for several hours after the logarithmic phase. In addition, the toxigenicity of the strain was kept unchanged in this medium for at least 40 transfers, while it was liable to drop sooner when maintained in the PYF medium as reported before (Murata et al., 1965).

Table 11. Effect of the inoculum size on the growth and toxin production of C. perfringens

\begin{tabular}{|c|c|c|c|c|c|c|}
\hline \multirow{3}{*}{ Experiment } & \multicolumn{6}{|c|}{ Inoculum size* } \\
\hline & \multicolumn{3}{|c|}{ (a) $10^{8} / 4 \mathrm{ml}$} & \multicolumn{3}{|c|}{ (b) $10^{5} / 4 \mathrm{ml}$ (one loopful) } \\
\hline & Growth & $\begin{array}{c}\text { Toxin } \\
(\mathrm{TD} / \mathrm{ml})\end{array}$ & Final $\mathrm{pH}$ & Growth & $\begin{array}{c}\text { Toxin } \\
\text { (TD/ml) }\end{array}$ & Final $\mathrm{pH}$ \\
\hline I & 0.75 & 10 & 7.2 & 0.85 & 10 & 7.4 \\
\hline II & 0.72 & 12 & 7.2 & 0.83 & 10 & 7.4 \\
\hline III & 0.88 & 6 & 7.4 & 0.79 & 5 & 7.4 \\
\hline IV & 0.77 & 12 & 7.1 & - & 10 & 7.5 \\
\hline $\mathrm{V}$ & 0.66 & 10 & 7.0 & 0.64 & 7 & 7.2 \\
\hline
\end{tabular}

* Inoculum size was shown by the number of viable cells. Incubation period was $6 \mathrm{hr}$ in (a) and $16 \sim 18 \mathrm{hr}$ in (b). 


\section{DisCUSSION}

Adequate balances of metallic elements are required not only for growth of microorganisms but also for syntheses of specific factors responsible for the virulence of pathogenic bacteria (Brown, 1964 ; Weinberg, 1962, 1966). Little is known about the role played by metallic ions in the processes of toxin production by $C$. perfringens, though there have been many reports on the effects of metallic ions on growth, morphology and metabolism of the organisms (Pappenheimer and Shaskan, 1944; Boyd, Logan and Tytell, 1948 ; Webb, 1949 ; Bard and Gansalus, 1950 ; Shanker and Bard, 1952, 1955 $\mathrm{a}, \mathrm{b}$; Fuchs and Bonde, 1957). Iron was the only metal presumed to influence the production of alpha toxin (Pappenheimer and Shaskan, 1944). We have demonstrated that quality and quantity of metallic ions in the medium required for toxin production were different from those needed for growth in many respects (Murata et al., 1965). The concentration of phosphate, $\mathrm{Zn}^{2+}, \mathrm{Fe}^{2+}$ and probably $\mathrm{Mg}^{2+}$ should be controlled more rigidly for toxin production than for growth.

A high concentration of phosphate was required for toxin production, though rather harmful for growth. The results in Table 2 and Fig. 2 show that it is not phosphate ion but monovalent cations which actually regulate the toxin production. Such an activity was not manifested by a single ion; both potassium and sodium ions were able to enhance toxin production to a certain extent, though potassium excess was rather harmful (Table 3). Divalent cations did not replace the monovalent ones (Table 6), probably because of their inhibitory activity for the growth and toxin production (see below).

The results in Tables 5 and 8 indicate that the effect of the monovalent cations may not be restricted to the production of a certain specific toxin. The fact that no alpha toxin was detectable within the cells grown in the basal medium indicates that the effect is not merely the release of the toxin already produced within the cells. Therefore, the monovalent cations may enhance the general synthetic activity of the organism. Although it is too early to make an explanation on the mechanism of the activity, it may be plausible to conclude that the increased osmotic pressure may enhance the protein synthesis, as shown by Brown (1961, 1964) with marine bacteria. Alternative explanations may be that sodium or potassium ion stimulates a certain enzyme system (Skou, 1957 ; Crisley, 1963 ; Drapeau and MacLeod, 1963 ; Miller and Avi-Dor, 1964 ; Holmes and Halvorson, 1965) or that the cations may influence the transport of the essential nutrients (Wheeler et al., 1965). Further studies are required to elucidate the mechanism.

A high concentration of phosphate in SM 65 may have another merit in giving a strong buffer action to the medium. The $\mathrm{pH}$ of the culture was prone to decline in a low phosphate medium to a value below 5.0 which is unfavorable for toxin production (Gale and van Heyningen, 1942). The acid production seemed to differ depending on each experiment and such a fluctuation apparently resulted from different conditions of the seed culture (Soda et al., 1968).

Though monovalent cations may enhance the toxin production the autolysis was often marked in a low phosphate medium enriched with salts and buffer (Fig. 3 and 4). It may be possible that the membrane structure might suffer from some conformational changes by enhanced protein synthesis (Brown 1961). Evidences have been shown that membranes of microorganisms may undergo structural changes by altering 
the ionic strength or composition of the media (Abram and Gibons, 1960, 1961 ; Henneman and Umbreit, 1964 ; Brown, 1964). Changes in membrane structure may render the organism susceptible to the autolysis.

Divalent cations did not enhance the toxin production in a low-phosphate medium but prevented the autolysis (Table 7). Probably the cations may serve to stiffen the membrane structure by neutralizing excess negative charge produced by active protein synthesis as suggested by many workers (Mueller, Rudin and Wesscott, 1962; Brown, 1962 ; Razin, Morowitz and Terry, 1965 ; Asbell and Eagon, 1966). However, divalent cations except for $\mathrm{Ca}^{2+}$ were shown to be harmful for toxin production at a concentration necessary to prevent the autolysis. In some experiments where the lysis was vigorous, $\mathrm{Ca}^{2+}$ apparently increased the yield of the toxin. This activity, however, may be an indirect one due to the prevention of early autolysis, since the ion per se was not favorable for toxin production whenever the autolysis was negligible.

Though the mechanism of the inhibition of the toxin production by divalent cations has not yet been clarified, a decline in the final $\mathrm{pH}$ was observed invariably at their excess. It may be plausible to conclude that divalent cations affect the carbohydrate metabolism as illustrated with iron by Pappenheimer and Shaskan (1944) and Bard and Gansalus (1960). However, the exact mechanism of this awaits further study. It is of interest to cite here the role of zinc (and manganese to a less extent) in the toxin production (Murata et al., 1965). In contrast to the monovalent cations which may stimulate the general synthetic process, zinc seems to be connected with a certain special process in the synthesis of toxin, since its elimination did not affect the growth, as shown before. Details on this problem will appear in a separate communication.

The fact that alpha toxin was produced with a small inoculum and that the toxigenicity of the strain was maintained for more than 40 transfers in the synthetic medium may be sufficient to exclude the possibility that some toxin promoting factors were carried over accidentally into the synthetic medium from the seed culture. However, a still unknown factor $(\mathrm{s})$ in complicated media may play some role in promoting the toxin production, since the yield of alpha toxin produced in our medium was about $30-50 \%$ of the peptone medium.

\section{REFERENCES}

ABRAM, D. AND GiBBons, N. E. (1960) : Turbidity of suspensions and morphology of red halophilic bacteria as influenced by sodium chloride concentrations, Canad. J. Microb., 6, 535-543.

ABRAM, D. AND GiBBons, N. E. (1961): The effect of chlorides of monovalent cations, urea, detergents, and heat on morphology and the turbidity of suspensions of red halophilic bacteria. Canad. J. Microbiol., 7, 741-750.

Asbell, M. A. AND EAGON, R. G. (1966): The role of multivalent cations in the organization and structure of bacterial cell walls, Biochem. Biophys. Res. Comm., 22, 664-671.

BARD, R. C. AND GANSAlus, I. C. (1950): Glucose metabolism of Clostridium perfringens: Existence of a metallo-aldolase. J. Bacteriol., 59, 388-400.

Boyd, M. J., Logan, M. A. AND Tytell, A. A. (1948) : The growth requirements of Clostridium perfringens (welchii) BP6K, J. Biolog. Chem., 174, 1013-1035.

BROwN, A. D. (1961): Effects of salt concentration during growth on properties of the cell envelope of a marine pseudomonad, Biochim. Biophys. Acta, 49, 585-588.

BRown, A. D. (1962): The peripheral structures of gram-negative bacteria. III. Effects of cations on proteolytic degradation of the cell envelope of a marine preudomonad. Biochim. 
Biophys. Acta, 62, 132-144.

BRown, A. D. (1964) : Aspects of bacterial response to the ionic environment, Bacteriol. Rev. $28,296-329$.

CRISLEY, F. D. (1963): Effect of sodium chloride on growth, glucose utilization, and acid production in Proteus vulgaris. J. Bacteriol., 86, 346-347,

DRAPEAU, G. R. AND MACLEOD, R. A. (1963) : Nutrition and metabolism of marine bacteria. XII. Ion activation of adenosine triphosphatase in membranes of marine bacterial cells. J. Bacteriol., 85, 1413-1419.

FuCHS, A. R. AND BONDE, G. J. (1957) : The nutritional requirements of Clostridium perfringens. J. gen. Microbiol., 16, 317-329.

Gale, E. F. AND van Heyningen, W. E. (1942): The effect of the $\mathrm{pH}$ and the presence of glucose during growth on the production of $\alpha$ and $\theta$ toxins and hyaluronidase by Clostridium welchii. Biochem. J. 36, 624-630.

Henneman, D. H. AND Umbreit, W. W. (1964) : Factors which modify the effect of sodium and potassium on bacterial cell membranes. J. Bacteriol., 6, 1266-1273.

Holmes, P. K. and Halvorson, H. O. (1965): Purification of salt-requiring enzyme from an obligately halophilic bacterium. J. Bacteriol., 90, 312-315.

JAYKo, L. G. AND Lichstein, H. C. (1959): Nutritional factors concerned with growth and lecithinase production by Clostridium perfringens. J. inf. Dis., 104, 142-151.

Logan, M. A., Tytell, A. A., Danielson, I. And Griner, A. (1945) : Production of Clostridium perfringens alpha toxin. J. Immunol., 51, 317-328.

MilleR, S. AND AVI-Dor, Y. (1964): Studies on the mechamism of potassium-stimulated respiration in Escherichia coli. J. gen. Microbiol., 36, 123-131.

MulleR, P., Rudin, D. O., Tien, H. T. ANd WescotT, W. C. (1962): Reconstitution of cell membrane structure in vitro and its transformation into an excitable system. Nature, 194, 979-980.

Murata, R., Yamada, T. AND Kameyama, S. (1956): Production of alpha toxin of Clostridium perfringens. I. Preparation of the reproducible peptone medium for the production of the toxin of high potency. Japan. J. Med. Sci. Biol., 9, 81-91.

MURATA, R. AND YAMAMOTO, A. (1964): A synthetic medium for production of alpha toxin by Clostridium perfringens. Japan. J. Med. Sci. Biol., 17, 211-213.

Murata, R., Yamamoto, A., SodA, S. AND Ito, A. (1965): Nutritional requirements of Clostridium perfringens PB6K for alpha toxin production. Japan. J. Med. Sci. Biol., 18. 189-202.

Pappenheimer, A. M., Jr. AND Schaskan, E. (1944): Effect of iron on carbohydrate metabolism of Clostridium welchii. J. Biochem., 155, 265-275.

Razin, S., Morowitz, H. J. AND TERRY, T. M. (1965) : Membrane subunits of Mycoplasma laidlawii and their assembly to membranelike structures. Proc. nat. Acad. Sci., 54, 219225.

Shanker, K. AND BARD, R. C. (1952): The effect of metallic ions on the growth and morphology of Clostridium perfringens. J. Bacteriol., 63, 279-290.

SHANKER, K. AND BARD, R. C. (1955 a): Effect of metallic ions on the growth, morphology, and metabolism of Clostridium perfringens. I. Magnesium. J. Bacteriol., 69, 436-443.

SHANKER, K. AND BARD, R. C. (1955 b): Effect of metallic ions on the growth, morphology, and metabolism of Clostridium perfringens. II. Cobalt. J. Bacteriol., 69, 444-448.

Skou, J. C. (1957): The influence of some cations on an adenosine triphosphatase from peripheral nerve. Biochim. Biophys. Acta, 23, 394-401.

SodA, S., Yamamoto, A., Ito, A. AND Murata, R. (1968) : On the maintenance of toxigenicity of seed cultures of Clostridium perfringens $\mathrm{PB} 6 \mathrm{~K}$ with special reference to alpha toxin. Japan. J. Med. Sci. Biol., 21, 91-94.

Tsukamoto, M., Yamamoto, A. ANd Murata. R. (1963) : Effect of some synthetic peptides on the alpha-toxin production by Clostridium perfringens PB6K. Japan. J. Med. Sci. Biol., 
$16,213-216$.

WEBB, M. (1949): The influence of magnesium on cell division. J. gen. Microbiol., 3, 410417.

WeINBERG, E. D. (1962): Trace-Metal control of specific biosynthetic processes. Perspectives in Biol. Med., 5, 432-445.

WEINBERG, E. D. (1966) : Roles of metallic ions in host-parasite interactions, Bacteriol. Rev., 30, 136-151.

Wheeler, K. P., Inui, Y., Hollenberg, P. F., Eavenson, E. and Christensen, H. N. (1965) : Relation of amino acid transport to sodium-ion concentration (PN 41036), Biochem. Biophys. Acta, 109, 620-622.

Willis, A. T. (1964): Anaerobic Bacteriology in Clinical Medicine, 2nd ed., Butterworths, London. 